\title{
Phosphate fertilization regulates arbuscular mycorrhizal symbiosis in roots of soybean (Glycine max L.) cultivars in a humid tropical soil
}

\author{
Nurudeen Olatunbosun ADEYEMI ${ }^{1,2}$, Olanrewaju Emmanuel ONI ${ }^{1}$, Paul Abayomi Sobowale SORE \\ $\mathrm{MI}^{1}$, Ademola ADEBIYI ${ }^{1}$, Adebanke OLUBODE ${ }^{3}$, Olufemi AJAO ${ }^{1}$
}

Received December 17, 2020; accepted August 17, 2021. Delo je prispelo 17. decembra 2020, sprejeto 17. avgusta 2021

\begin{abstract}
Phosphate fertilization regulates arbuscular mycorrhizal symbiosis in roots of soybean (Glycine max L.) cultivars in a humid tropical soil

Abstract: The effect of phosphate fertilization on arbuscular mycorhizal symbiosis and grain yields of soybean cultivars was investigated on P deficient soil. A two-year field study (2017-2018) consisting of two soybean cultivars (TGx 1448-2E and TGx 1440-1E) and three phosphate rates [0, 20 and $40 \mathrm{~kg} \mathrm{P}_{2} \mathrm{O}_{5} \mathrm{ha}^{-1}$ ) was laid out in a randomized complete block design with three replications. The results showed that $\mathrm{P}$ fertilization significantly $(p<0.001)$ reduced AMF root colonization of both cultivars in the two cropping years. The arbuscular, vesicular, internal hyphae and total colonization in the root cortex of the soybean cultivars were significantly $(p<0.001)$ reduced with high $\mathrm{P}(40 \mathrm{~kg})$ application. However, moderate $\mathrm{P}(20 \mathrm{~kg})$ promote AMF symbiosis in roots of 'TG $x$ 1448-2E. Dry mass (root and shoot), $P$ uptake and grain yield of the soybean cultivars were significantly $(p<0.001)$ increased with increasing $\mathrm{P}$ ferilization. There was a strong linear relationships between root colonization and total dry matter mass $(r=0.81)$, P uptake $(r=0.81)$ and grain yield $(r$ $=0.85)$. Thus, it could be concluded that moderate $\mathrm{P}$ fertilizer application is needed to promote mycorrhizal symbiosis in soybean and sustainable crop production in humid tropical soil.
\end{abstract}

Key words: arbuscules; biomass; internal hyphae; soybean; phosphorus uptake; vesicles; Nigeria
Gnojenje s fosfatom uravnava arbuskularno mikorizno simbiozo v koreninah sort soje (Glycine max L.) v vlažnih tropskih tleh

Izvleček: Učinek gnojenja s fosfatom na arbuskularno mikorizno simbiozo (AMF) in pridelek zrnja je bil preučevan pri sortah soje na tleh s pomanjkanjem fosforja. Dvoletni poljski poskus (2017-2018), ki je vključeval dve sorti soje ('TGx 1448-2E' in 'TGx 1440-1E') in tri gnojenja s fosfatom $\left[0,20\right.$ in $40 \mathrm{~kg} \mathrm{P}_{2} \mathrm{O}_{5} \mathrm{ha}^{-1}$ ) je bil izveden kot popolni naključni bločni poskus s tremi ponovitvami. Rezultati so pokazali, da je gnojenje s fosforjem značilno $(p<0,001)$ zmanjšalo mikorizacijo obeh sort soje v dveh letih poskusa. Število arbuskulov, veziklov in interkortikalnih hif se je pri obeh sortah soje značilno zmanjšalo $(p<0,001)$ pri uporabi velikih količin $\mathrm{P}$ $(40 \mathrm{~kg})$. Zmerno gnojenje s P $(20 \mathrm{~kg})$ pa je pospešilo AMF simbiozo v koreninah 'TG x 1448-2E'. Suha masa (korenin in poganjkov), privzem $\mathrm{P}$ in pridelek zrnja so se pri obeh sortah soje značilno povečali ( $p<0,001)$ s povečevanjem gnojenja $s$ fosforjem. Obstajala je močna linearna, pozitivna povezava med kolonizacijo korenin in celokupno suho maso $(r=0,81)$, privzemom fosforja $(r=0,81)$ in pridelkom zrnja $(r=0,85)$. Iz vsega tega lahko zaključimo, da je potrebno zmerno gnojenje s fosforjem za pospeševanje mikorizne simbioze soje za njeno trajnostno pridelavo v vlažnih tropskih tleh.

Ključne besede: arbuskuli; biomasa; interkortikalne hife; soja; privzem fosforja; vezikli; Nigerija

1 Federal University of Agriculture, Abeokuta, College of plant Science and Crop production, Department of Plant Physiology and Crop Production, , P.M.B.2240, Alabata, Ogun State, Nigeria

2 Corresponding author, e-mail: adeyemisworld@gmail.com; adeyemino@funaab.edu.ng, https://orcid.org/0000-0001-6341-775X

3 Federal University of Agriculture, Abeokuta, College of plant Science and Crop production, Department of Soil Science and Land Management, P.M.B.2240, Alabata, Ogun State, Nigeria 


\section{INTRODUCTION}

Arbuscular mycorrhizal fungi (AMF) belonging to the phylum Glomeromycota form symbiotic relationships with roots of most terrestrial plants, inculding most agricultural crops (Smith and Read, 2008). AMF symbiosis is the most common type and very frequent in most soils, especially phosphorus (P) defiecient soils of tropical and sub-tropical regions (Brundrett, 2009). AMF is of great relevance in most agroecosystems because of their contributions in improving uptake of water and nutrients, especially $\mathrm{P}$ and to a lesser extent nitrogen in exchange for plant derived carbon ((Jiang et al., 2017). The mediated improvement in nutrients uptake by AMF helps to increased growth and development of plants, and confer resistance to abiotic and biotic stress (Smith and Read, 2008; Gianinazzi et al., 2010). Moreover, AMF improve soil structure and helps to mitigate drought and salinity stress, in plants (Smith et al., 2011). Thus, AMF symbiosis may be critical to increasing crop yields and ecosystem sustainability in a low-input manner (Castillo et al., 2016).

Despite the long history of AMF coevolution with most plants in various ecosystems, resulting in their adaptation to specific areas (Gosling et al., 2013), majority of research on AMF symbiosis involves controlled experiments such as laboratory or pots and ignore native AMF taxa that could alter plant responses (Adeyemi et al., 2019). In addition, there are limited reports on the influence of various farming practices such as fertilizer application, tillage practices on AMF symbiosis in humid tropical soils of Nigeria. It is evident that important gaps in understanding the regulation of AMF symbiosis still remain. Previuos studies have shown that intensive application of chemical fertilizers, particularly phosphate fertilizers reduced development of AMF symbiosis in roots of plants (Johnson et al., 2015). Conversely, in soils with inherent soil availability, the benefit of the symbiosis could be enhanced with moderate P fertilization (Chalk et al., 2006). Interestingly, the use of native AMF as biological fertilizers has been recommended because of their better adaptation to local conditions. (Berruti et al., 2016).

Soybean (Glycine max L.) is an economically important crop grown in various parts of the world because of its high quality protein and oil content for human and livestock consumption. Root colonization of oil-seed crops including soybean by native AMF taxa has been reported earlier (Adeyemi et al., 2019). Despite this, in Nigeria, little attention has been paid to development of AMF symbiosis of native taxa under different phospahte fertilization (Sakariyawo et al., 2016; Adeyemi et al., 2017, 2019, 2020). Thus, little is known on how $\mathrm{P}$ fertilization regulates AMF symbiosis in this agroecosystem. Thus, assessing the regulation of AMF symbiosis might serve to establish a link in the use of native AMF as biolfertilizers for improving crop productivity and sustainable agriculture.

To the best of our knowledge, this present work would be an encompassing assessment of phosphate fertilization effects on AMF symbiosis in the humid tropical soil of southwest Nigeria. The objective of the present was to investigate how phosphate fertilization regulates arbuscular mycorhizal symbiosis, dry matter accumulation, $\mathrm{P}$ uptake as well as grain yield of soybean cultivars on $\mathrm{P}$ deficient soil in a humid tropical soil of southwest Nigeria. Thus, this study hypothesized that: 1) phosphate fertilization would influence the development of AMF symbiosis in roots of the soybean cultivars, 2) AMF symbiosis in soybean would be regulated by varietal difference between the soyean cultivars, and 3 ) assuming the soybean cultivars differ in terms of dry matter accumulation and $\mathrm{P}$ uptake, root colonization of the cultivars will be also different.

\section{MATERIALS AND METHODS}

\subsection{STUDY AREA}

The study was carried out at the Teaching and Research Farms of the Federal University of Agriculture, Abeokuta, Ogun State, Nigeria (Latitude $7^{\circ} 15^{\prime} \mathrm{N}$, Longitude $3^{\circ} 28^{\prime}$ E.), during the 2017 and 2018 cropping seasons. The soil was sandy loam and classified as kandic paleustalf in the alfisol order of the United States Department of Agriculture (USDA) soil taxonomy. The area is tropical derived savanna and is characterized by bimodal rainfall pattern; it has two distinctive seasons (dry and wet). Mean annual temperature is about $27.5^{\circ} \mathrm{C}$, and the total annual rainfall was $839.7 \mathrm{~mm}$ and $1403.3 \mathrm{~mm}$ in 2017 and 2018 respectively with maximum rainfall in the period between May to September. The pre-planting soil analysis was done by collecting soil samples from the study field at a depth of 0-20 $\mathrm{cm}$. The collected soil samples were air dried, bulked and sieved in the laboratory through a $2 \mathrm{~mm}$ mesh to determine the basic physical and chemical soil properties of the study area. The particle size distribution (clay, silt, sand) was determined using the hydrometer method and soil $\mathrm{pH}$ (1:1 soil: water ratio) using the electrometric method (Page, Miller and Keeney, 1982). The organic carbon using Walkley-Black wet oxidation method (Nelson and Sommers, 1982), available phosphorus using the Bray No. 1 method (Bray and Kurtz, 1945), total nitrogen using Kjeldahl distillation method 
(Bremner and Mulvaney, 1982) and exchangeable basic cations using ammonium acetate method (Moss, 1961). The modified wet sieving and sucrose techniques of Giovannetti and Mosse (1980) were used to determine the initial mycorrhizal spore density in the soil (48 spores/100 $\mathrm{g}$ of soil). The experimental site had no previous known history of inoculation with AMF. The native AMF spore density in the soil was determined using modified wet sieving and sucrose techniques of Giovanetti and Mosse (1980) in $100 \mathrm{~g}$ of soil. The initial soil properties are presented in Table 1.

\subsection{EXPERIMENTAL TREATMENTS AND DE- SIGN}

The study consisted of two soybean cultivars (TGx 1448-2E and TGx 1440-1E) and three phosphate rates [0 (P0), 20 (P20) and $\left.40(\mathrm{P} 40) \mathrm{kg} \mathrm{P}_{2} \mathrm{O}_{5} \mathrm{ha}^{-1}\right)$ laid out in a randomized complete block design with three replications. The seed of the soybean cultivars were obtained from the Institute of Agricultural Research and Training, Ibadan, Nigeria.

The land was manually cleared and the experimental blocks were marked out using pegs, measuring tape and ropes, and then labeled after double plowing. Each block size was $4 \mathrm{~m} \times 4 \mathrm{~m}\left(16 \mathrm{~m}^{2}\right)$ and net plot size of $3 \mathrm{~m} \times 3 \mathrm{~m}\left(9 \mathrm{~m}^{2}\right)$. The distance between blocks was 1 $\mathrm{m}$ and $2 \mathrm{~m}$ between replicates. The soybean seeds were sown manually in a row at a depth of $2 \mathrm{~cm}-5 \mathrm{~cm}$ and spacing of $50 \mathrm{~cm}$ (inter-row) $\times 10 \mathrm{~cm}$ (intra-row). The $\mathrm{P}$ fertilizer was supplied using single superphosphate

Table 1: Selected basic soil properties of the study site

\begin{tabular}{ll}
\hline Soil Property & Value \\
\hline $\mathrm{pH}\left(1: 1 \mathrm{H}_{2} \mathrm{O}\right)$ & 5.7 \\
Sand $(\%)$ & 70.8 \\
Silt $(\%)$ & 12.7 \\
Clay $(\%)$ & 16.5 \\
Textural Class & Sandy loam \\
Total N $(\%)$ & 0.09 \\
Organic matter $(\%)$ & 1.77 \\
Available P (mg kg $\left.{ }^{-1}\right)$ & 6.13 \\
$\mathrm{~K}\left(\mathrm{cmol} \mathrm{kg}^{-1}\right)$ & 0.61 \\
Ca $\left(\mathrm{cmol} \mathrm{kg}^{-1}\right)$ & 6.68 \\
$\mathrm{Mg}\left(\mathrm{cmol} \mathrm{kg}^{-1}\right)$ & 1.47 \\
$\mathrm{Na}\left(\mathrm{cmol} \mathrm{kg}^{-1}\right)$ & 0.29 \\
Initial spore density & 125 spores/100 g of soil \\
\hline
\end{tabular}

(SSP, $20 \% \mathrm{P}_{2} \mathrm{O}_{5}$ ) immediately after sowing. Weeds were controlled manually using hoes and cutlasses.

\subsection{DATA COLLECTION}

\subsubsection{Root colonization}

Fine roots of soybean were collected from 10 randomly selected plants in each plot and washed in tap water before storage in $50 \%$ ethanol to preserve the roots. The roots were rinsed thoroughly to remove the ethanol, cut into $1 \mathrm{~cm}$ segments before they were cleared in hot $\mathrm{KOH}$ solution $\left(10 \% \mathrm{w} / \mathrm{v}\right.$, at $\left.90{ }^{\circ} \mathrm{C}\right)$ for 1 hour and stained with trypan blue lacto-glycerol (1:1:1:0.5 g) at $90^{\circ} \mathrm{C}$ for 30 minutes (Phillips and Hayman, 1970). The percentage root length colonized by AMF (\% RLC) was measured on 25 root segments under a stereo microscope at $100 \times$ magnification scoring the presence or absence of arbuscules, vesicles and hyphae (Giovannetti and Mosse, 1980). The \% RLC was calculated using the equation 1 according to Adeyemi et al. (2021).

$$
\% \mathrm{RLC}=\frac{\text { Number of colonized root segments }}{\text { Total number of root segments }} \times 100
$$

\subsubsection{Soybean biomass and grain yield}

Ten plants were harvested from each plot, separated into roots and shoots, and then oven-dried at 70 ${ }^{\circ} \mathrm{C}$ to a constant. The roots and shoots were added to determine the total dry mass. At harvest maturity, the pods from each plot were manually threshed, air-dried to determine the grain yield in $\mathrm{kg}$ per hectare.

\subsubsection{Phosphorus uptake}

The oven-dried soybean samples were ground into fine particles. Sub-samples ( $1 \mathrm{~g}$ ) were taken and analyzed colorimetrically by the molybdate blue method (Murphy and Riley, 1962) after digesting in concentrated $\mathrm{H}_{2} \mathrm{SO}_{4}$ to determine $\mathrm{P}$ concentration. The $\mathrm{P}$ uptake was determined by multiplying the $\mathrm{P}$ concentration by the dry matter.

\subsection{STATISTICAL ANALYSIS}

Data collected were analyzed by two-way analysis of variance using Genstat Release 12.1, (Copyright 
2009, VSN International Ltd). Root colonization (\%) was subjected to arcsine transformation for normalization of the data. Fishers protected LSD was used to separate means at significance level of $p<0.05$. Microsoft excel 2016 was used to generate the figures.

\section{RESULTS AND DISCUSSION}

The effect of $\mathrm{P}$ rates, varieties and their interaction on root colonization, dry biomass, $\mathrm{P}$ uptake and grain yield are summarized in Table 2 . The total root colonization of the soybean cultivars ranged from 18.3-60.8\% in 2017 and $18.3-59.2 \%$ in 2018 cropping season in this study (Fig. 1). This result suggest a moderate capacity of the infection of the native AMF in the study area. This confirms the presence of native or indegenous AMF and the symbiotic association with soybean roots in the derived savannah of Nigeria. Previous study in this agroecosystem have reported the presence of indiegenous AMF and root colonization of agrcultural crops such as soybean, maize, sunflower and sesame (Adeyemi et al., 2019, 2020; Sakariyawo et al., 2019), which showed similar root colonization to those obtained in the present study. 'TGx 1448-2E' was highly colonized by AMF compared to 'TGx 1440-1E' on average in both seasons. The difference observed in root colonization between the two cultivars can be explained by the nutrients demand, particularly $\mathrm{P}$ and carbon supplied from the cultivars, allowing both symbiont partners to adjust the symbiosis accordingly (Kiers et al., 2011). This is in agreement with reports of Hetrick et al. (1996), who reported that mycorrhizal dependency was positively correlated with $\mathrm{P}$ uptake. The ability of the cultivars to uptake $\mathrm{P}$ depends on the morphological and physiological characteristics of their roots (Schachtman et al., 1998; Rao et al., 1999). In addition, plant species with high phosphatase exudation in the

Table 2: Factorial ANOVA of treatment effects on root colonization, growth and P uptake of soybean in 2017 and 2018 cropping seasons

\begin{tabular}{|c|c|c|c|}
\hline & \multicolumn{3}{|c|}{$p$-values } \\
\hline & Cultivars & P rates & Cultivar $\times P$ rates \\
\hline \multicolumn{4}{|c|}{2017} \\
\hline \multicolumn{4}{|c|}{ Root colonization } \\
\hline Arbuscules & 0.710 & $<0.001$ & 0.303 \\
\hline Hyphae & 0.002 & $<0.001$ & 0.051 \\
\hline Vesicles & 0.152 & $<0.001$ & 0.418 \\
\hline Total & $<0.001$ & $<0.001$ & 0.033 \\
\hline \multicolumn{4}{|l|}{ Dry mass } \\
\hline Shoot & 0.240 & $<0.001$ & 0.487 \\
\hline Root & 0.286 & $<0.001$ & 0.978 \\
\hline Total & 0.431 & $<0.001$ & 0.591 \\
\hline P uptake & 0.045 & 0.025 & 0.820 \\
\hline Grain yield & $<0.001$ & 0.001 & 0.460 \\
\hline \multicolumn{4}{|c|}{2018} \\
\hline \multicolumn{4}{|c|}{ Root colonization } \\
\hline Arbuscules & 0.31 & $<0.001$ & 0.667 \\
\hline Hyphae & 0.023 & $<0.001$ & 0.221 \\
\hline Vesicles & 0.069 & $<0.001$ & 0.540 \\
\hline Total & 0.051 & $<0.001$ & 0.313 \\
\hline \multicolumn{4}{|l|}{ Dry mass } \\
\hline Shoot & 0.240 & $<0.001$ & 0.487 \\
\hline Root & 0.373 & $<0.001$ & $<0.988$ \\
\hline Total & 0.398 & $<0.001$ & 0.547 \\
\hline P uptake & $<0.001$ & $<0.001$ & 0.593 \\
\hline Grain yield & $<0.001$ & $<0.001$ & 0.186 \\
\hline
\end{tabular}


roots may not depend on AMF colonization. Furthermore, Adeyemi et al. (2021a) reported that mycorrhizal colonization of soybean varies greatly within cultivars. Werner and Kiers (2015) have also reported spatial precision among plant species or cultivars in selecting symbiotic partners.

Our results showed that phosphate fertilization significantly $(p<0.001)$ affected the root colonization (arbuscules, internal hyphae, vesicles and total) of the soybean cultivars by AMF in both cropping seasons (Fig.1). The root colonization of plants by AMF has been reported to be influenced by several factors including crop management practices such as plant species or cultivars selection, soil $\mathrm{P}$ availability, $\mathrm{P}$ fertilization (Fernández et al., 2011; Verbruggen et al., 2013; Adeyemi et al., 2019). Application of high phosphate, 40 $\mathrm{kg} \mathrm{P}_{2} \mathrm{O}_{5}$ ha $^{-1}(\mathrm{P} 40)$ significantly $(p<0.001)$ suppressed percentage root colonization in both soybean cultivars in terms of arbuscular, hyphae, vesicular and total root colonization of the soybean roots. This conforms to the reports of previous studies (Ortas, 2012; Wang et al., 2016; Thioub et al., 2019), who observed that high P fertilization disrupt mycorrhizal symbiosis. The increased root colonization in control plots in this study can be explained by the inherent low soil $\mathrm{P}$ availability of the study area (Tab. 1). However, the enhanced root coloni- zation of 'TGx 1448-2E' with moderate phosphate rate (P20) in the present study confirms the result of Chalk et al. (2006), who reported that increased root colonization in soil with low available $\mathrm{P}$ when fertilized with moderate $\mathrm{P}$ than unfertilized soil. Among the AMF structures examined for the soybean root colonization, internal hyphae colonization was significantly $(p<$ 0.051 ) dominant in both cultivars and under all $P$ rates in this study. This can be explained by its function in transfer of nutrients and water to the plants (Smith and Read, 2008). The reduced arbuscular colonization can be explained by the early and premature degradation of arbuscules in the root cortex (Breuillin et al., 2010). The significant reduction of the presence of the AMF structures in the root cortex under high $\mathrm{P}$ fertilization could decrease $\mathrm{P}$ uptake via the mycorrhizal pathway and increase $\mathrm{P}$ uptake via plant direct pathway, thus suppressing development of AMF symbiosis (Smith et al., 2011). Additionally, the significant decrease in root colonization with high $\mathrm{P}$ fertilization can be linked with inhibition of plant symbiotic genes and symbiotic related P transporters (Breuillin et al., 2010). Berruti et al. (2014) reported that high fertilizer levels in soil drastically alters the interaction between plants and soil microbes. In addition, the report of Fernández et al.

A.

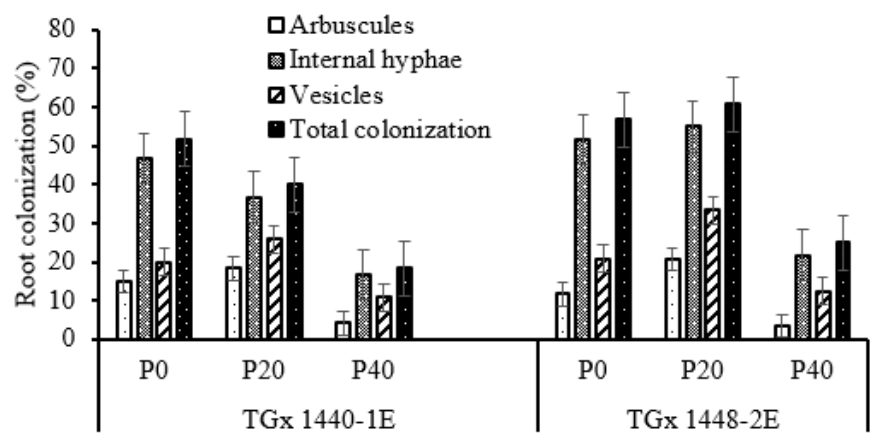

B.

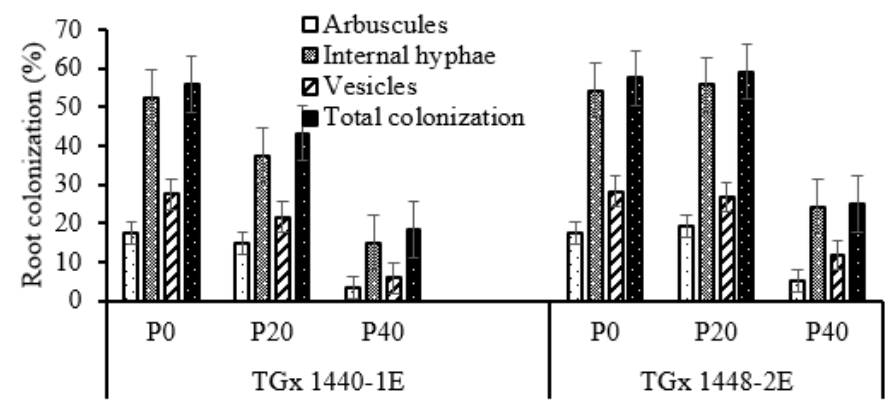

Fig. 1: Percentage of root colonized (arbuscules, internal hyphae, vesicles, and total colonization) in soybean cultivars as influenced by phosphate rates during 2017 (A) and 2018 (B) cropping seasons. P0, P20 and P40 indicate 0,20 and $40 \mathrm{~kg} \mathrm{P}_{2} \mathrm{O}_{5}$ ha ${ }^{-1}$ respectively. Bars indicate mean values \pm standard errors of differences $(\mathrm{n}=3)$ at $p<0.05$ 
A.

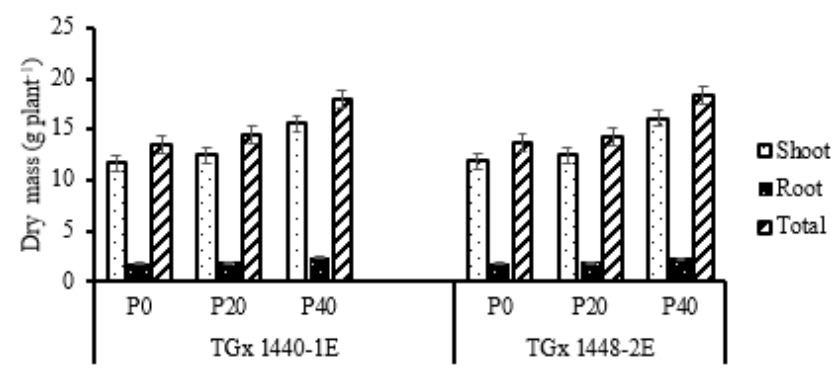

B.

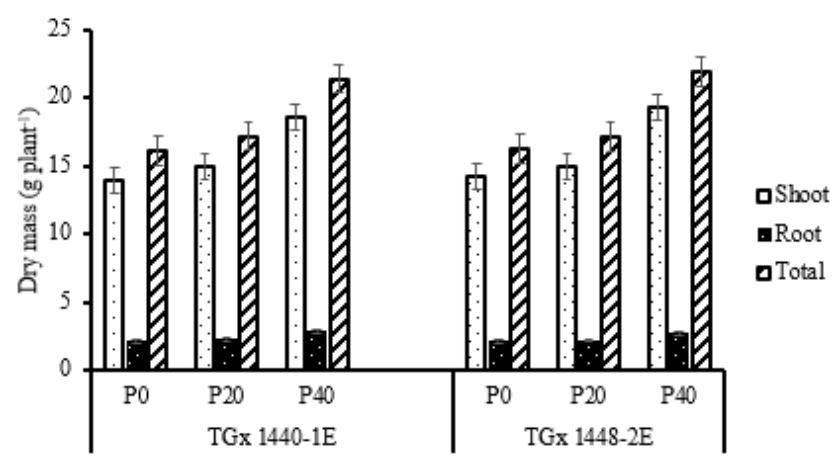

Fig. 2: Dry mass (shoots, roots and total) of soybean cultivars as influenced by phosphate rates during 2017 (A) and 2018 (B) cropping seasons. P0, $\mathrm{P} 20$ and $\mathrm{P} 40$ indicate 0,20 and $40 \mathrm{~kg} \mathrm{P}_{2} \mathrm{O}_{5}$ ha $^{-1}$ respectively. Bars indicate mean values \pm standard errors of differences $(\mathrm{n}=3)$ at $p<0.05$

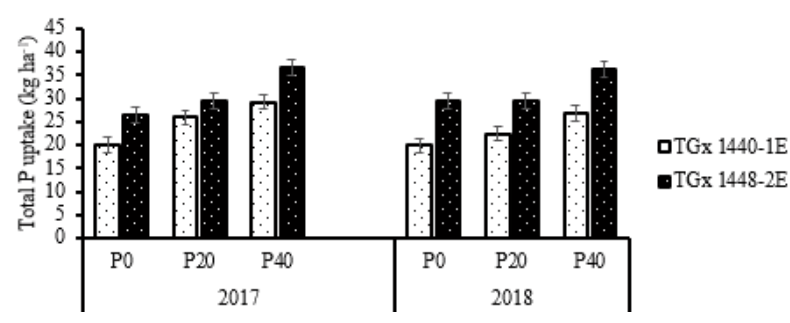

Fig. 3: Total phosphorus uptake in soybean cultivars as influenced by phosphate rates during 2017 and 2018 cropping seasons. P0, P20 and P40 indicate 0, 20 and $40 \mathrm{~kg} \mathrm{P}_{2} \mathrm{O}_{5} \mathrm{ha}^{-1}$ respectively. Bars indicate mean values \pm standard errors of differences $(\mathrm{n}=3)$ at $p<0.05$.

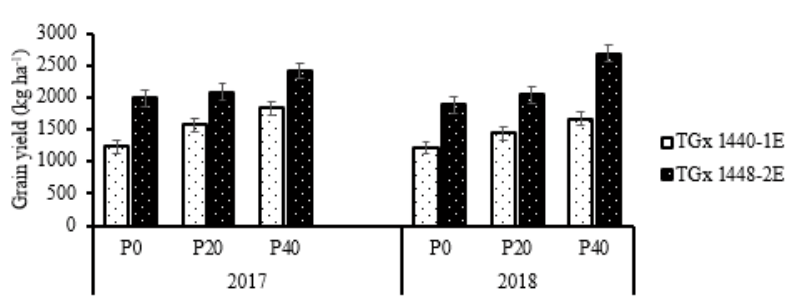

Fig. 4: Grain yield of soybean cultivars as influenced by phosphate rates during 2017 and 2018 cropping seasons. P0, $\mathrm{P} 20$ and $\mathrm{P} 40$ indicate 0,20 and $40 \mathrm{~kg} \mathrm{P}_{2} \mathrm{O}_{5}$ ha $^{-1}$ respectively. Bars indicate mean values \pm standard errors of differences ( $\mathrm{n}$ $=3)$ at $p<0.05$. 
A.

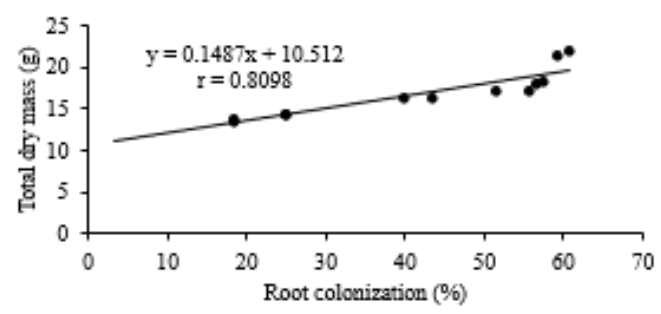

B.

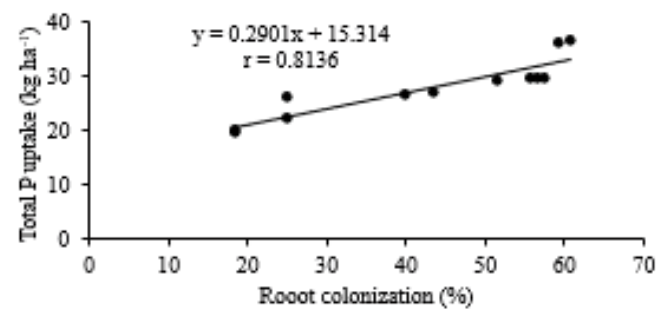

c.

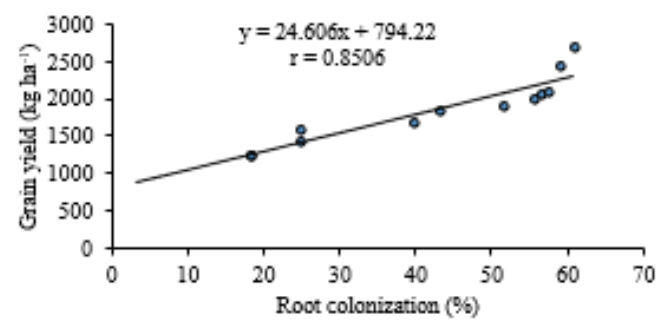

Fig. 5: Relationships between root colonization and total dry mass (A), P uptake (B) and grain yield (C) of soybean

(2011) showed that AMF root colonization in soybean was negatively related to soil available phosphorus.

The present study also revealed the positive effect of phosphate fertilization on plant biomass, $\mathrm{P}$ uptake and grain yield of the soybean cultivars. In both cultivars, the dry biomass (Fig. 2), P uptake (Fig. 3) and grain yield (Fig. 4$)$ significantly $(p<0.001)$ increased with increasing $P$ rates compared to the control in both seasons. Promotion of plant growth including soybean has been reported in several other studies. The increased growth of the soybean cultivars with increasing $\mathrm{P}$ rate could be attributed to the role of $\mathrm{P}$ in major metabolic processes in plants such as photosynthesis, energy transfer, biosynthesis of macromolecules, respiration and signal transduction involve phosphorus (Khan et al., 2010).

The results of this study confirmed very strong linear relationships between the root colonization by AMF and total dry matter $(r=0.81)$, P uptake $(r=0.81)$ and grain yield $(r=0.85)$. This indicates that increase in root colonization increased dry matter, $\mathrm{P}$ uptake and grain yield and vice versa (Fig. 5). Several studies have reported that root colonization by AMF has a positive effect on plant growth (Thioub et al., 2019; Adeyemi et al., 2020; 2021b). This is often attributed to increased water and nutrients uptake, particularly $\mathrm{P}$ (Cozzolino et al., 2013; Williams et al., 2013; Adeyemi et al., 2021c).

\section{CONCLUSION}

The results of the present study show that AMF were present and associated with roots of soybean in transitory rainforest of southwest Nigeria. Phosphate fertilization regulates AMF symbiosis in roots of soybean cultivars. High phosphate fertilization suppressed percentages of root colonization of the soybean cultivars in both cropping seasons. Moderate phosphate fertilization (P20) promote AMF symbiosis in roots of 'TGx 1448-2E' in terms of root colonization (arbuscules, internal hyphae, vesicles and total colonization). The biomass (shoot and root), P uptake and grain yield of both soybean cultivars were promoted with increasing phosphate fertilization, with the highest observed under $\mathrm{P} 40$ rate. The present study also conclude that the mycorrhizal symbiosis, $\mathrm{P}$ uptake and grain yield can be enhanced in soybean with moderate $\mathrm{P}$ fertilizer application. Thus, it is necessary to develop sustainable farming practices with reduce $\mathrm{P}$ fertilizer application to maximize the benefits of the AMF symbiosis in agricultural soils. However, further research is needed need to gain a better understanding of how AMF taxa functional roles differ in diverse ecosystems in Nigeria in response to different agronomic practices including complementary studies on AMF nutrient demands, host effects and feedbacks mechanisms.

\section{REFERENCES}

Adeyemi, N., Sakariyawo, O. and Atayese, M. (2017). Yield and yield attributes responses of soybean (glycine max l. merrill) to elevated $\mathrm{CO} 2$ and arbuscular mycorrhizal fungi inoculation in the humid transitory rainforest. Notulae Scientia Biologicae, 9(2), 233-41. https://doi.org/10.15835/ nsb9210002

Adeyemi, N. O., Atayese, M. O., Olubode, A. A. (2019). Identification and relative abundance of native arbuscular mycorrhizal fungi associated with oil-seed crops and maize (Zea mays L.) in derived savannah of Nigeria. Acta Fytotechnica et Zootechnica, 22(3), 84-89. https://doi. org/10.15414/afz.2019.22.03.84-89.

Adeyemi, N. O., Atayese, M. O., Olubode, A. A. and Akan, M. E. (2020). Effect of commercial arbuscular mycorrhizal fungi inoculant on growth and yield of soybean under 
controlled and natural field conditions. Journal of Plant Nutrition, 43(4), 487-99. https://doi.org/10.1080/0190416 7.2019.1685101

Adeyemi, N. O., Atayese, M. O.,, Sakariyawo, O. S., Azeez, J. O., Olubode, A. A., Ridwan, M., Adebiyi, A., Oni, A., and Ibrahim, I. (2021a): Influence of different arbuscular mycorrhizal fungi isolates in enhancing growth, phosphorus uptake and grain yield of soybean in a phosphorus deficient soil under field conditions, Communications in Soil Science and Plant Analysis, https://doi.org/10.1080/00103 624.2021 .1879117

Adeyemi, N. O., Atayese, M. O., Sakariyawo, O. S., Azeez, J. O., and Ridwan, M. (2021b). Arbuscular mycorrhizal fungi species differentially regulate plant growth, phosphorus uptake and stress tolerance of soybean in lead contaminated soil. Journal of Plant Nutrition, 44(11), 1633-1648. https://doi.org/10.1080/01904167.2021.1871748

Adeyemi, N. O., Atayese, M. O., Sakariyawo, O. S., Azeez, J. O., Sobowale, S. P. A., Olubode, A., Mudathir, R., Adebayo, R., and Adeoye, S. (2021c). Alleviation of heavy metal stress by arbuscular mycorrhizal symbiosis in Glycine $\max (\mathrm{L}$.) grown in copper, lead and zinc contaminated soils. Rhizosphere, 18, 100325. https://doi.org/10.1016/j. rhisph.2021.100325

Berruti, A., R. Borriello, A. Orgiazzi, A. C. Barbera, E. Lumini, and V. Bianciotto. (2014). Arbuscular mycorrhizal fungi and their value for ecosystem management. Biodiversity - the Dynamic Balance of the Planet, 159-191. https://doi. org/10.5772/58231

Berruti, A., Lumini, E., Balestrini, R., (2016). Arbuscular mycorrhizal fungi as natural biofertilizers: let's benefit from past successes. Frontier in Microbiology, 6, 1. https://doi. org/10.3389/fmicb.2015.01559

Bray, R. H., and L. T. Kurtz. (1945). Determination of total, organic, and available forms of phosphorus in soils. Soil Science, 591), 39-46. https://doi.org/10.1097/00010694194501000-00006

Bremner, J. M., and C. S. Mulvaney (1982). Nitrogen - Total. In Methods of soil analysis. American society of agronomy. Soil science of America, ed. A. L. Page, R. H. Miller, and D. R. Keeney, 595-624, Madison, Wisconsin, USA: American Society of Agronomy. https://doi.org/10.2134/ agronmonogr9.2.2ed.c31

Breuillin, F., J. Schramm, M. Hajirezaei, A. Ahkami, P. Favre, U. Druege, B. Hause, M. Bucher, T. Kretzschmar, E. Bossolini, C. Kuhlemeier, E. Martinoia, P. Franken, U. Scholz and D. Reinhardt. (2010). Phosphate systemically inhibits development of arbuscular mycorrhiza in petunia hybrida and represses genes involved in mycorrhizal functioning. The Plant Journal, 64, 1002-17. https://doi.org/10.1111/j.1365313X.2010.04385.X

Brundrett M.C. (2009). Mycorrhizal associations and other means of nutrition of vascular plants: understanding the global diversity of host plants by resolving conflicting information and developing reliable means of diagnosis. Plant and Soil, 320, 37-77. https://doi.org/10.1007/s11104008-9877-9

Castillo, C., Borie, F., Oehl, F., et al. (2016). Arbuscular mycorrhizal fungi biodiversity: prospecting in southern-central zone of Chile. A review. Journal of Soil Science and Plant Nutrition, 16, 400-422. https://doi.org/10.4067/S071895162016005000036

Chalk, P.M., Souza, R.D.F., Urquiaga, S., et al. (2006). The role of arbuscular mycorrhiza in legume symbiotic performance. Soil Biology and Biochemistry, 38, 2944-2951. https://doi.org/10.1016/j.soilbio.2006.05.005

Cozzolino, V., Di Meo, V., and Piccolo, A., (2013). Impact of arbuscular mycorrhizal fungi applications on maize production and soil phosphorus availability. Journal of Geochemical Exploration, 129, 40-44. https://doi.org/10.1016/j. gexplo.2013.02.006

Fernández M.C., Boem F.H.G., and Gerardo R.G. (2011). Effect of indigenous mycorrhizal colonization on phosphorus-acquisition efficiency in soybean and sunflower. Journal of Plant Nutrition and Soil Science, 174, 673-677. https://doi.org/10.1002/jpln.201000109

Gianinazzi, S., Gollotte, A., Binet, M.N., et al. (2010). Agroecology: the key role of arbuscular mycorrhizas in ecosystem services. Mycorrhiza, 20(8), 519-530. https://doi. org/10.1007/s00572-010-0333-3

Giovanneti, M. and Mosse, B. (1980). An evaluation of techniques for measuring vesicular-arbuscular mycorrhizal infection in roots. New Phytologist, 84(3), 489-500. https:// doi.org/10.1111/j.1469-8137.1980.tb04556.x

Gosling, P., Mead, A., Proctor, M., et al. (2013). Contrasting arbuscular mycorrhizal communities colonizing different host plants show a similar response to a soil phosphorus concentration gradient. New Phytologist, 198(2), 546-556. https://doi.org/10.1111/nph.12169

Jiang, Y.N., Wang, W.X., Xie, Q.J., et al. (2017). Plants transfer lipids to sustain colonization by mutualistic mycorrhizal and parasitic fungi. Science, 356, 1172-1175. https://doi. org/10.1126/science.aam 9970

Johnson, N.C., Wilson, G.W.T., Wilson, J.A., et al. (2015). Mycorrhizal phenotypes and the law of the minimum. New Phytologist, 205, 1473-1484. https://doi.org/10.1111/ nph.13172

Khan, M. S., Zaidi, A., Ahemad, M., et al. (2010). Plant growth promotion by phosphate solubilizing fungi - current perspective. Archives of Agronomy and Soil Science, 56(1), 73-98. https://doi.org/10.1080/03650340902806469

Kiers Et, Duchamel M, Beesetty Y, et al. (2011). Reciprocal rewards stabilize cooperation in the mycorrhizal symbiosis. Science, 333, 880-882. https://doi.org/10.1126/science. 1208473

Murphy, J., and Riley, J. P. A. (1962). Modified single solution method for the determination of phosphate in natural waters. Analytica Chimica Acta, 27, 31-36. https://doi. org/10.1016/S0003-2670(00)88444-5

Nelson D.W. and L.E. Sommers. (1982). Total carbon, organic carbon, and organic matter. In Methods of Soil Analysis. A. L. Page, R.H. Miller, D.R. Keeney (Eds.). Part II, 2nd ed., 539-580, American Society of Agronomy, Madison, USA. https://doi.org/10.2134/agronmonogr9.2.2ed.c29

Ortas, I. (2012). The effect of mycorrhizal fungal inoculation on plant yield, nutrient uptake and inoculation effectiveness under long-term field conditions. Field Crop Research, 125, 35-48. https://doi.org/10.1016/j.fcr.2011.08.005 
Page, A. L., R. H. Miller, and D. R. Keeney. (1982). Method of soil analysis, part 2 Agronomy monograph 9, part 2 agr. Ed. Wisconsin, Madison: American Society of Agronomy

Phillips, J., and Hayman, D. (1970). Improved producers for clearing roots and vesicular arbuscular mycorrhizal fungi for rapid assessment of infection. Transactions of the British Mycological Society, 55, 158-160. https://doi.org/10.1016/ S0007-1536(70)80110-3

Rao, 1.M., Friesen, D.K., and Osaki, M. (1999): Plant adaptation to phosphorus limited tropical soil. In Handbook of Plant and Crop Stress. Ed. M Pessarakli, p. 61-95, Marcel Dekker, Inc. New York. https://doi.org/10.1201/9780824746728. ch4

Sakariyawo O.S., Adeyemi, N.O., Atayese, M.O., et al. (2016) Growth, assimilate partitioning and grain yield response of soybean (Glycine max L. Merrrill) varieties to carbon dioxide enrichment and arbuscular mycorrhizal fungi in the humid rainforest. Agro-science, 15, 29-40. https://doi. org/10.4314/as.v15i2.5

Schachtman, D.P., Reid, R.J., and Ayling, S.M. (1998): Phosphorus uptake by plants: From soil to cell. Plant Physiology, 116, 447-453. https://doi.org/10.1104/pp.116.2.447

Smith S.E, Jakobsen L, Grønlund M, et al. (2011). Roles of arbuscular mycorrhizas in plant phosphorus nutrition: interactions between pathways of phosphorus uptake in arbuscular mycorrhizal roots have important implications for understanding and manipulating plant phosphorus acquisition. Plant Physiology, 156, 1050-1057. https://doi. org/10.1104/pp.111.174581

Smith, S.E., and Read, D.J. (2008): Mycorrhizal symbiosis, 3rded. Academic Press, London, UK.

Thioub, M., Ewusi-Mensah, N., Sarkodie, J., et al. (2019). Arbuscular mycorrhizal fungi inoculation enhances phosphorus use efficiency and soybean productivity on a haplic acrisol. Soil \& Tillage Research, 192, 174-186. https:// doi.org/10.1016/j.still.2019.05.001

Verbruggen, E., Van Der Heijden, M. G. A., Rillig, M. C., et al. (2013). Mycorrhizal fungal establishment in agricultural soils: factors determining inoculation success. New Phytologist, 197, 1104-1109. https://doi.org/10.1111/j.14698137.2012.04348.x

Wang, X., Zhao, S., and Bücking, H., (2016). Arbuscular mycorrhizal growth responses are fungal specific but do not differ between soybean genotypes with different phosphate efficiency. Annals of Botany, 118, 11-21. https://doi. org/10.1093/aob/mcw074

Werner, G. and Kiers, E. T. (2015). Partner selection in the mycorrhizal mutualism. New Phytologist. https://doi. org/10.1111/nph.13113

Williams, A., Ridgway, H.J., and Norton, D.A., (2013). Different arbuscular mycorrhizae and competition with an exotic grass affect the growth of Podocarpus cunninghamii Colenso cuttings. New Forest, 44, 183-195. https://doi. org/10.1007/s11056-012-9309-9 